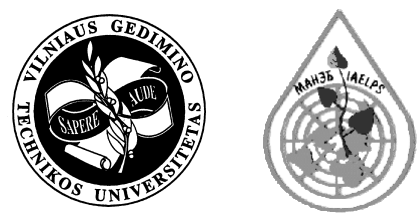

\title{
TESTING ON NOISE LEVEL PREVAILING AT MOTOR VEHICLE PARKING LOTS AND NUMERAL SIMULATION OF ITS DISPERSION
}

\author{
Pranas Baltrènas, Dainius Kazlauskas, Egidijus Petraitis
}

\author{
Dept of Environmental Protection, Vilnius Gediminas Technical University, \\ Sauletekio al. 11, LT-10223 Vilnius-40, Lithuania \\ E-mail:dakaz@ap.vtu.lt
}

Received 25 Sept 2003; accepted 24 Oct 2003

\begin{abstract}
In Vilnius and in other bigger towns the noise generated by mobile sources accounts for up to $90 \%$ of the total noise level in a town. A high noise level is detected at motor vehicle parking lots. To measure this noise level, testing was carried out at guarded parking lots which were divided into certain types. One lot of each type was chosen for testing. The number of measuring spots was conditioned by the size of a lot. The data obtained during testing reveal that the highest noise level is generated not at a parking lot but on a nearby street. Such conclusions are proved by the results of testing carried out at a parking lot on $\breve{C}$. Sugihara street. Although this lot parks over 100 vehicles, the equivalent noise level is $47 \mathrm{dBA}$. Basing on the testing data, the numeral simulation of the noise dispersion in areas in the vicinity of parking lots has been run with the help of the numeral simulation software IMMI.
\end{abstract}

Keywords: traffic, noise, parking lots, modelling, numeral simulation.

\section{Introduction}

The number of vehicles has been continually growing in Lithuania. Unfortunately, the number of vehicles older than 10 years has also been growing. The development of motor transport causes pollution increase in air, water and soil as well as physical pollution of the environment: noise and electromagnetic field.

Extremely huge impact of motor transport on the environment is seen in the main places of its concentration, $\mathrm{i}$ e at big crossroads and at major parking lots [1]. Due to the increasingly growing number of cars, the issues of car parking and guarding will need a more effective solution.

The motorization level that is annually growing poses an increasing problem related to car parking. This problem is especially relevant for those who work and live in the central part of Vilnius. People living in residential areas encounter the problem of car guarding which could be solved by guarded parking lots and garages. The following main types of parking lots may be singled out:

Parking lots built close to public buildings and public institutions. Their aim is to service the flow of temporally coming customers and employees. Parking of cars on these lots usually is rather short and an active motion of cars is seen. They usually are small lots for a small number of cars at the side of the street.
Parking lots built near major supermarkets. They are likely to be the biggest parking lots that simultaneously may park more than 1000 cars. Movement of cars is intensive on them. An especially active movement is seen on rush hours, when most comers to supermarkets finish their work, and on weekends. Cars are parked on these lots for an hour at longest. It should be emphasized that the traffic of cargo transport bringing goods is also going on close to parking lots at supermarkets. Buses may also be parked there.

Garages. It is an enclosure or a building for keeping and technical maintenance of motor vehicles. It can be of general or specialized purpose: for cars, buses, special purpose motor vehicles. The most common purpose of a garage is parking of a car when it is not maintained. Two main types of garages may be singled out: of metal, of brick, underground, multi-storey. Some time ago, metal and brick garages were most popular. Now metal garages are refused, as they occupy the area that is needed for urban development and disintegrate the landscape. Brick garages are built in the vicinity of residential buildings. Recently, multi-storey and underground garages are being built, which will help to solve the problems of car parking in Vilnius. It is intended that employees and visitors of institutions located downtown will park their cars there.

Parking lots in the vicinity of blocks of flats. When building parking lots near blocks of flats, it is necessary 
to consider the fact that they may be used not only for a long-term parking but also should be available for temporarily coming visitors and special transport (emergency services, cargo transportation, garbage disposal). Those residents who keep their cars in outlaying garages or guarded parking lots could also use these lots on a temporal basis.

Guarded car-parking lots. Motor vehicles may be parked on this type of parking lots for several hours and even for several days. Usually these lots are surrounded by a metal or brick fence, and motor vehicles are guarded for 24 hours.

Sound tests have been carried out at guarded parking lots.

Parking lots are the main places of motor vehicle collection in Vilnius. They park 50 to 2000 motor vehicles. Naturally, such a great number of vehicles is another source of environmental pollution [2]. Thus, it is essential to find out the level of noise generated at such motor vehicle parking lots as well as to define the impact of such lots on the total background noise level of Vilnius. Specific tests have revealed the real impact of parking lots on physical pollution of the environment.

The aim of this paper is to find out the noise level at parking lots and, basing on the results obtained, to perform numeral simulation of the change in the additional noise level with the help of the numeral simulation software IMMI.

\section{Testing methods}

Analysing the network of guarded parking lots in Vilnius, all of them were divided into several categories. Such a categorization was based on several criteria: the lot size and diversity of vehicles parked. The aim of such a division was to find out the noise level prevailing at parking lots of different size:

- parking lots with less than 100 places for parking;

- parking lots with 101 to 500 places for parking;

- parking lots for light and heavy vehicle parking.

The description of parking lots goes together with the description of surrounding areas. Due regard has been paid to what purpose buildings are located close to the lots, the distance to the lots, local relief, heavy traffic streets in close vicinity, other sources of physical pollution (plants, fuel stations, airports, etc).

Noise-measuring spots have been chosen at the parking lots taking into consideration several factors. First of all, the size of a lot has been taken into consideration. When a lot is designed for not more than 100 vehicles, it is enough to measure the noise generated in the centre of the lot and at measuring spots at a distance of $1 \mathrm{~m}$ from the lot. However, to obtain higher-precision measurements of the prevailing noise level for bigger parking lots (for more than two hundred vehicles), such a number of spots for measuring acoustic noise at such lots is not sufficient. In the course of measuring, additional measuring spots are set within the area of a parking lot. One measuring spot is set in the centre of a lot; other four spots are set on the diagonals joining the corners of a lot. Each of the other 4 measuring spots is set at a distance of 1 metre from the lot. One measuring spot is set near the entrance to a lot, as the heaviest traffic of motor vehicles to be parked is seen there. Carrying out measuring at parking lots intended for more than 1000 vehicles, more measuring spots should be set. To this end, a certain "grid" is formed with measuring spots set on its junctions. The size of the "grid" meshes is chosen taking into consideration the peculiarities of the local relief, dimensions of a lot, the number of places for parking and other features typical of each parking lot. The distance between measuring spots should not exceed 25 metres.

Taking into consideration the impact of noise generated by a parking lot on the environment, more measuring spots may be set. It is of the most importance to find out the noise level at residential dwellings located in the vicinity of guarded parking lots. To that end, measuring spots at a distance of not more than several metres from a dwelling are set. In areas close to residential dwellings, hospitals, schools noise is measured at least at three spots located at a distance of 1-2 m from the wall of a building, at a height of 1,2-1,5 $\mathrm{m}$ of the area surface [3]. Measuring is carried out in accordance with the methods set in ISO 96-1. It is also essential to take into consideration the level of transportgenerated noise within a building. That level is calculated with the help of formulas. It is very important to carry out such type of calculations at the lots located in the vicinity of hospitals, educational institutions for children and other institutions for special purposes [4].

Levels of acoustic noise are measured using noise detector of Class 10 or 2 containing internal or external filters with 1/1 octave band [5]. Devices are calibrated before and after noise measuring. If calibration results differ by more than $2 \mathrm{~dB}$, the noise measuring should be repeated. The acoustic noise at parking lots is measured with the help of noise and vibration detector VŠV $003 \mathrm{M} 2$.

The noise level at measuring spots was measured 3 times with the intervals of half an hour. The noise level was measured according to characteristics $\mathrm{A}$, as it best suits low-intensity sounds $(20-55 \mathrm{~dB})$. It imitates the curve of sensitivity of human hearing under practically recorded noise levels generated by transport and industrial objects [6]. It is often given as dBA. The noise level was also set in the octave band, taking into account different frequencies of noise.

With regard to time, transport noise is unstable. An equivalent level of sound is set for its measuring. For that, the sound level $L_{A}(\mathrm{dBA})$ is measured at different moments of time. An equivalent sound level is calculated with the help of the following formula [7]:

$$
L_{\text {Aekv. }}=10 \lg \frac{1}{T} \int^{10^{0,1 L} d t},
$$


where: $T$ - average values of measured noise in time.

Noise level measuring is carried out holding an amplifier BPM-101 with a capsule attached to it in an outstretched hand [8]. The amplifier may be turned to the noise generator. The noise detector transforms sound and mechanical oscillation of the object being tested into proportional electrical impulses which are measured and given in a scale.

Analysing the noise at guarded parking facilities of Vilnius, not all of them have been tested. One lot of each type has been chosen for testing, presuming that the same environmental pollution is detected at other lots of the same type.

The noise tests at parking lots located near Architektų and Ateities streets were carried out on working hours, from 6:30 a.m. to 8:30 a.m. and from 4:00 p.m. to 8:00 p.m. in December 2002. These hours have been chosen for measuring, as precisely on at that time the heaviest traffic of motor vehicles is seen at guarded parking lots. During an hour on the average 10 vehicles left the lot, while during the remaining time the number of the cars entering or leaving the area of the lot was only 30 .

Differently from the above-described lots, the noise level at the parking lot located near Č. Sugihara street was measured on working hours from 6:00 a.m. to 8:00 p.m. Such a time of measuring has been chosen to find out the dependence of the noise level at the lot on the time of the day. At first, the same as in previously described lots, noise tests at all the measuring spots were carried out on working days from 6:30 a.m. to 8.30 a.m. and from 4:00 p.m. to 8:00 p.m. in January 2003. The measuring has been carried out following the requirements provided in $\mathrm{HN}: 33-2001$.

\section{Testing results}

A guarded parking lot for up to 101 vehicles located on Architektų street has been chosen for noise testing. The choice of this lot has been influenced by several factors: the position of the lot in the city, residential dwellings close to the area of the lot, and a quiet street (Architektu str). The tests carried out at this lot give the best reflection of the acoustic noise level generated only at parking lots. There are no other sources generating a loud noise close to the street. On the northern side, a 12-storey residential dwelling is located at a distance of 10 metres from the street. On the eastern side, a grove is just next to the lot. On the southern side, a 12-storey residential dwelling is located at a distance of $20 \mathrm{~m}$ from the lot. On the western side, a grove and a 5-storey residential dwelling are located; the dwelling is at a distance of $60 \mathrm{~m}$ from the lot. This dwelling is separated from the lot by Architektu street. On the side of Architektu street, some part of the lot is planted with deciduous trees.

The noise level at this lot has been measured at 5 spots. Such a number of spots has been conditioned by the size of the lot. The spots have been chosen as follows: measuring spot 1 - in the centre of the lot, other ones - at a distance of 1 metre from the boundaries of the lot (Fig 1).

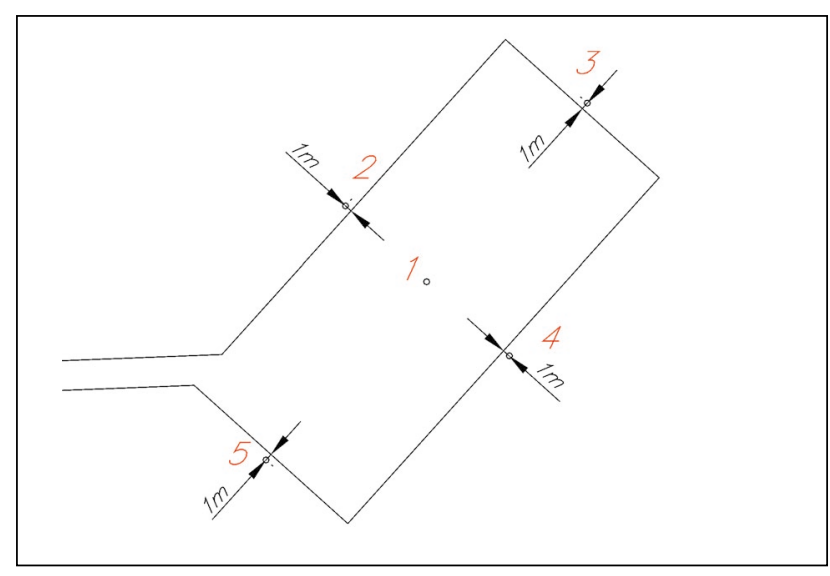

Fig 1. Layout of noise measuring spots at the parking lot on Architektu street: 1 - in the centre of the lot, 2-5 - at a distance of $1 \mathrm{~m}$ from the lot

The equivalent noise level at the spots of measuring differs only by $2-3 \mathrm{~dB}(\mathrm{~A})$ and on the average is $47 \mathrm{~dB}(\mathrm{~A})$. The lowest noise level has been recorded at the measuring spot 4 which is furthermost from Architektu street and closest to the grove. The highest noise level has been recorded at the measuring spot located close to the street. An entrance to the parking lot is located close to this spot of measuring. The distribution of the noise level, measured at this spot, on the octave band is presented in Fig 2. According to the data given in Fig 2, it is seen that the noise level in the whole octave band does not exceed the permitted noise level for the areas of residential dwellings provided in the Hygiene Norm HN:33-2001.

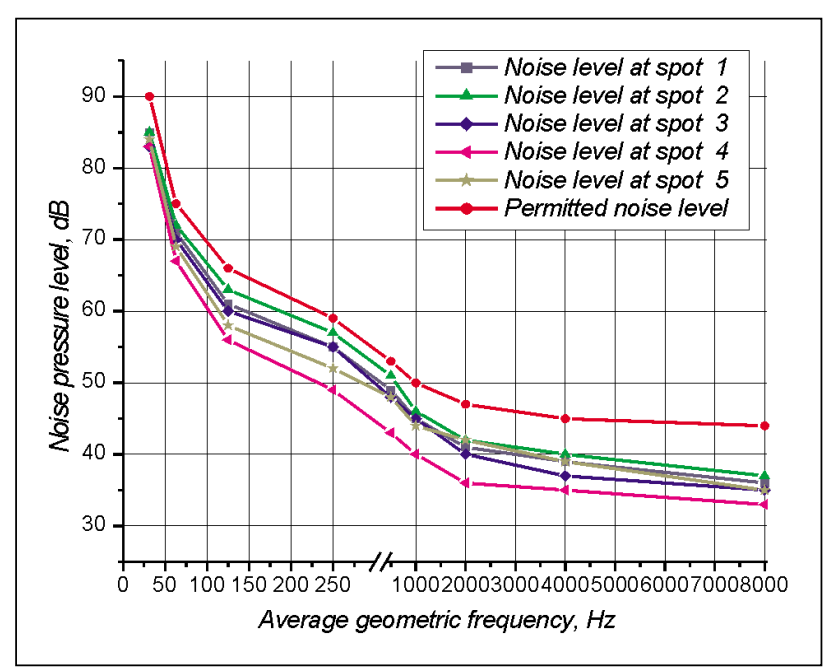

Fig 2. Distribution of the noise level recorded at the parking lot on Architektu street in the band of different frequencies 
A guarded parking lot located on the crossing of Ateities street and L. Gira street has been chosen for testing lots intended for parking light and heavy motor vehicles. On the northern side of the lot, a 5-storey residential dwelling is at a distance of 20 metres. Close to the lot trees are planted. On the eastern side, administrative buildings are situated just next to the boundary of the lot. On the southern side, Ateities street and further a grove are situated. On the south-western side, a school is located at a distance of 150 metres. On the western and north-western side, L. Gira street is situated next to the boundary of the lot, and multi-storey residential dwellings are located at a distance of 40 metres, and private residential houses are located further to the north-west. This lot also parks cargo and special transport. The southern part of the lot is intended for this type of transport and it covers one third of the total area.

The noise level at this lot has been measured at 9 spots. Such a selection of measuring spots has been conditioned by the size of the lot. The spots have been selected in the following order: measuring spot 5 - in the centre of the lot; measuring spots 2, 3, 7, 8 - within the area of the lot, and the remaining spots - at a distance of 1 metre from the lot (Fig 3).

At the spot located in the centre of the lot, the equivalent noise level of $66 \mathrm{dBA}$ has been recorded. A similar equivalent noise level has been recorded at spots $2,3,8,1$. There the measured equivalent noise level in the centre of the lot differs by 1-2 dBA. Fig 4 shows the distribution of the noise level of these spots on the octave band.

These spots are independent of the total surrounding noise level to the highest extent: spots 5, 2, 3 are in the centre of the lot and at a distance of 30-50 metres from L. Gira street; measuring spot 8 , although close to

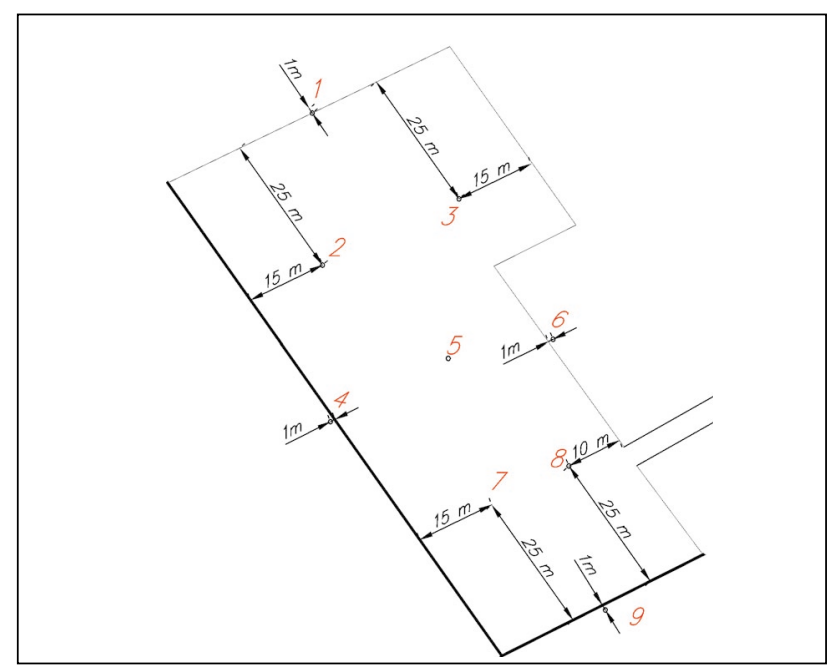

Fig 3. Layout of noise measuring spots at the parking lot on Ateities street: 5 - in the centre of the lot, 2, 3, 7, 8 within the lot, $1,4,6,9-$ at a distance of $1 \mathrm{~m}$ from the lot

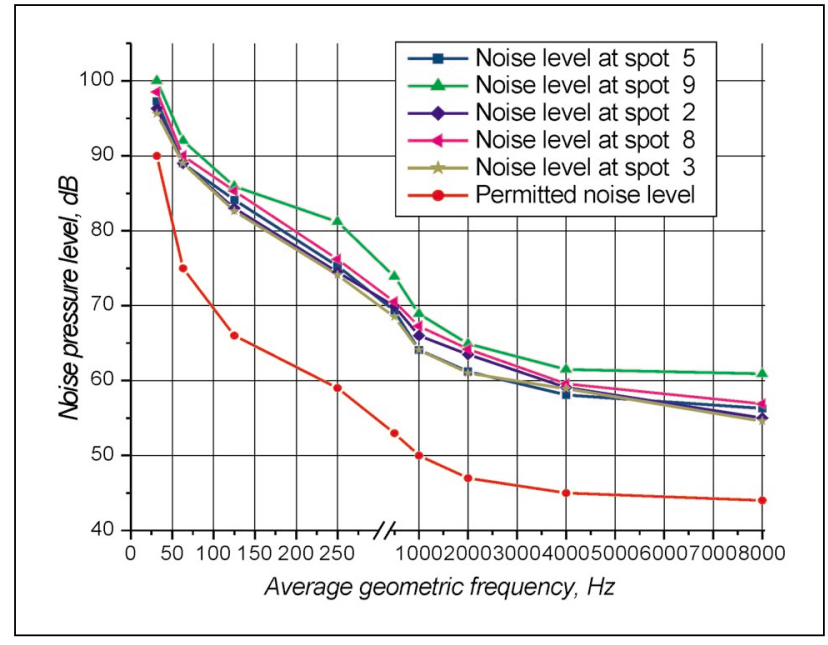

Fig 4. Distribution of the noise level recorded at the parking lot on Ateities street in the band of different frequencies

the entrance to the lot, is at a distance of 40 metres from Ateities street; spot 1, close to the lot, is at a distance of 50 metres from L. Gira street. The lowest level of noise has been recorded at spot 6 which is at the longest distance from L. Gira street and Ateities street. No wonder that the highest level of the equivalent noise has been recorded at measuring spots 4 and 9 . These spots are located at a distance of 3 metres from the streets. The level of noise permitted by the Hygiene Norm is exceeded at all the measuring spots. The highest overrun is detected on 250 and $8000 \mathrm{~Hz}$ octave bands. There the permitted noise level is exceeded by $17-20 \mathrm{~dB}$, while on the octave bands - by $7-15 \mathrm{~dB}$.

It should be noted that a high maximum noise level has been recorded at this lot. At measuring spots 7, 8 and 9 it is 93,93 and $96 \mathrm{dBA}$, respectively. Such a high noise level was recorded at the moment of starting the engines of cargo vehicles. These measuring spots were situated in the area of the lot intended for cargo and special-purpose transport. Parking of these motor vehicles conditioned a higher maximum level of noise and had an impact on the total equivalent noise level all over the parking lot.

Analysing the noise level at the parking lots for more than 101 motor vehicles, the parking lot located on Č. Sugihara street intended for 300 vehicles has been chosen. The lot and its approaches are surrounded by trees, no buildings are close to the lot. The area of the lot is divided into two parts: during testing half of the lot was occupied by the motor vehicles of the company AB "Vilniaus duona" (almost 100 vehicles), the rest area was occupied by light cars. Noise measuring has been carried out only in the part of the lot occupied by cars, as no traffic of motor vehicles was seen in the other part of the lot.

Measuring has been carried out at 8 spots. Such a choice of spots has been conditioned by the size of 
the lot. The spots have been chosen in the following order: measuring spot 5 - in the centre of the lot, measuring spots $2,3,7,8$ - within the area of the lot, and the remaining ones - at a distance of 1 metre from the boundaries of the lot. On the southern side of the lot, the noise level has not been measured, as it is the area of the lot intended for guarding the motor vehicles of AB "Vilniaus duona" (Fig 5).

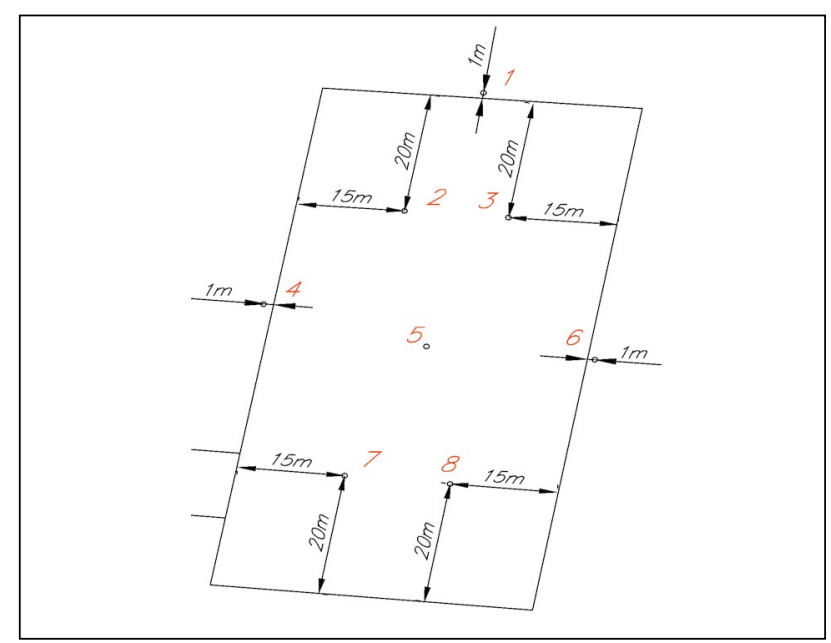

Fig 5. Layout of noise measuring spots at the guarded

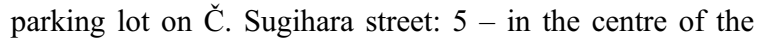
lot; 2, 3, 7, 8 - within the lot, 1, 4, 6 - at a distance of 1 metre from the area of the lot

The equivalent noise level at the measuring spots differs only by $2-3 \mathrm{dBA}$ and on the average is equal to $47 \mathrm{dBA}$. Fig 6 illustrates the distribution of the noise level recorded at the measuring spots on the octave band.

The highest noise level has been recorded at measuring spot 7. There the equivalent noise level is $50 \mathrm{dBA}$. The noise level is the highest at this spot due to the fact

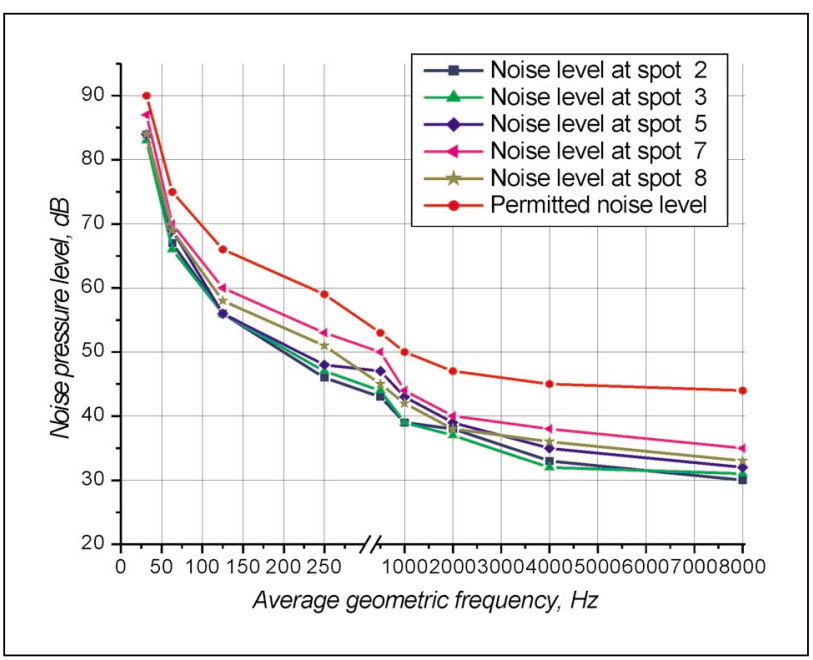

Fig 6. Distribution of the noise level recorded at the parking lot on $\breve{C}$. Sugihara street in the band of different frequencies that spot 7 is situated close to the entrance to the lot. All the coming or leaving motor vehicles pass that spot. It has been noticed that the further is the measuring spot away from the entrance to the lot, the lower acoustic noise level is recorded. The lowest noise level has been recorded at measuring spot 3 . This spot is furthermost from the entrance to the lot and the equivalent noise level at it is $46 \mathrm{dBA}$. These data allow concluding that the equivalent noise level at the parking lot on C. Sugihara street does not exceed the noise level permitted by the Hygiene Norm HN:33-2001.

To find out the dependence of the noise level at the lot on the time of the day, the noise measuring at spot 2 was carried out on working days from 6:00 a.m. to 8:00 p.m., measuring every half of an hour. This measuring spot has been chosen due to the fact that the highest level of the equivalent noise level has been detected at it.

The noise level within the area of the parking lot starts going up from 6:00 a.m. and the highest noise level is recorded at 7:30 a.m. Then the noise level starts gradually going down and at 10:00 a.m. it reaches 17 dBA. Before 2:00 p.m. the noise level hardly changes. From 2:30 p.m. the noise level starts going up. The maximum noise level is recorded at about 5:00 p.m. (51 dBA). By 8:00 p.m. the noise level is gradually going down to $17 \mathrm{dBA}$.

These measurements prove the previous presumption that the highest noise level is recorded at the parking lot during the period of the heaviest traffic on it (from 6:30 a.m. to 9:00 a.m. and from 3:30 p.m. to 6:30 p.m.). That is the time when most of drivers go to or return from work. Besides, the time given shows that it is not reasonable to carry out testing at guarded parking lots from 10:00 a.m. to 3:00 p.m., as the traffic during that period is very low and does not generate a loud acoustic noise.

\section{Simulation of noise dispersion}

Simulation of the dispersion of acoustic noise in the areas close to the parking lots of Vilnius has been carried out with the help of the software IMMI. The software is designed for numeral simulation of noise generated by different types of noise sources (motor vehicles, railway, industry, airports). It applies calculations based on ISO 9613. Besides, it may make calculations basing on the national standards of more than twenty countries. This software simulates noise dispersion in the environment taking into account meteorological conditions, relief, and artificial and natural obstacles. The results are presented graphically in the form of noise maps. The results can also be presented on a detailed result sheet [9].

Working with this software, first of all the initial data should be entered. The initial data are the following:

- a detailed map of the location being tested in 3D 
format which shows the buildings surrounding the area and their height, also the green zones and the average height of prevailing plants, the relief roughness, natural and artificial obstacles;

- noise sources; in the case of tests carried out it gives the measured equivalent noise levels at the measuring spots of the parking lot, the noise levels of nearby streets and crossings, the traffic-lights located close to the noise source of another type;

- meteorological conditions (wind speed, temperature, air humidity);

- coefficients of absorption reflection from obstacles. When the initial data is entered, calculations are made. Applying IMMI, the noise level at a measuring spot located at a certain distance from a noise source is calculated with the help of the following formula [10]

$$
L_{f T}(D W)=L_{\mathrm{w}}-A,
$$

where $L_{\mathrm{w}}-$ level of noise generated by the noise source (dB), $A$ - decrease in the noise level occurring when noise is spreading from the noise source to the measuring spot $(\mathrm{dB})$.

The value $A$ from formula 1 is calculated with the help of the following formula:

$$
A=A_{\text {div }}+A_{\text {atm }}+A_{g r}+A_{b a r}+A_{\text {misc }},
$$

where $A_{d i v}$ - the decrease in the noise level due to the distance $(\mathrm{dB})$. It is calculated as follows:

$$
A_{d i v}=\left[20 \lg \left(d / d_{0}\right)+11\right] \text {, }
$$

where $d$-distance between the noise source and the measuring spot $(\mathrm{m}), d_{0}$ - directive distance $(1 \mathrm{~m})$.

$A_{\text {atm }}$ - decrease in the noise level due to athmosphere absorption with the noise spreading within the distance $d$. It is calculated as follows:

$$
A_{\text {atm }}=\alpha \cdot d / 1000 \text {, }
$$

where $\alpha$ - atmosphere absorption coefficient $(\mathrm{dB} / \mathrm{km})$. It is chosen from the tables. This coefficient depends on the noise frequency, air temperature, air humidity and hardly depends on the atmospheric pressure.

$A_{g r}$ - decrease in the noise level due to the surface effect $(\mathrm{dB})$. This decrease occurs when the sound wave is reflected or absorbed on the terrain. It depends on the relief of the location and on the type of the terrain.

$A_{b a r}$ - decrease in the noise level due to the obstacles on the way of wave spreading. It depends on the geometric characteristics of the obstacle and their surface peculiarities.

$A_{\text {misc }}$ - decrease in the noise level caused by other effects, namely, in an area planted with bushes or trees, residential areas, in an area of a plant encountered on the way of wave spreading.

With the help of IMMI, calculations of the noise level applying the above formulas can be made all over the area tested or at a specific spot of that area. Besides, the noise level could be calculated at a different time of the day. To find out the noise level at a specific spot, a noise recipient should be put at that spot [11]. After calculations are made, a detailed report on the noise level at that spot will be given.
The results are presented graphically in the form of a noise level map. Zones of different noise levels are presented in different colours. The noise map is drawn only in the system of xy coordinates. In the system of xyz coordinates only the relief of the area tested and the buildings on that area are given.

During simulation not only the noise level generated at a parking lot is taken into account but also the acoustic noise generated on nearby streets. During simulation the same conditions as those during measuring were taken. During simulation the relief of the surrounding area and the height of nearby buildings were given; besides, the impact of the nearby green zones was taken into account.

The map of the noise level distribution at the parking lot on Architektu street resulting from the numeral simulation is presented in Fig 7.

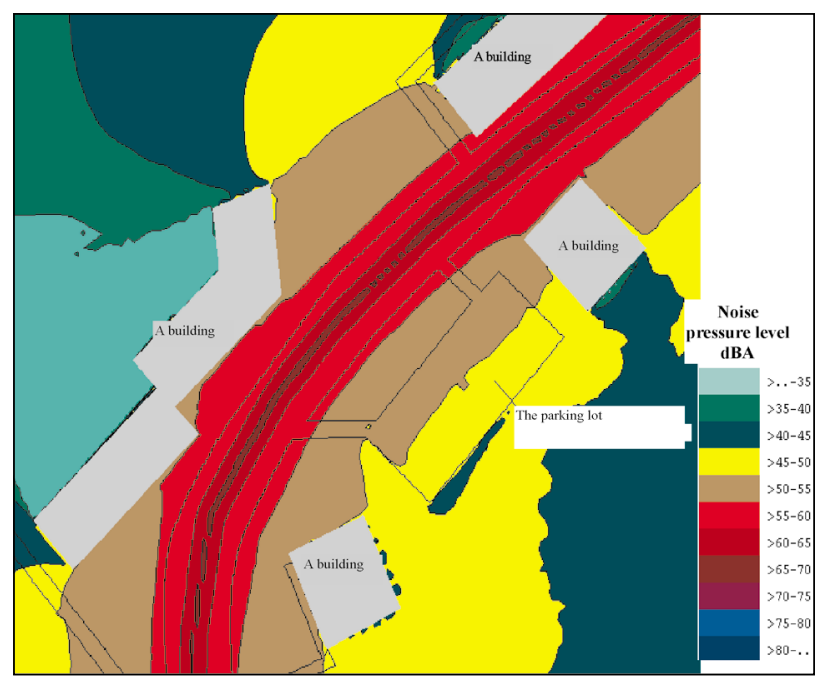

Fig 7. Results of the simulation of noise dispersion at the parking lot on Architektų street

It is obvious from Fig 7 that most of the noise on the area tested comes from the nearby Architektu street. This part of the lot is denoted by a brown colour which corresponds to the noise level of 50-55 dBA. In the part of the lot close to the grove the noise level reaches only about 45-50 dBA. It is obvious that the green "patch" on the map close to the lot means that the noise level in that area is only $40-45 \mathrm{dBA}$. Such a decrease in the noise level could be explained by the fact that this area is lower than the total area of the parking lot. Receding from the boundaries of the lot, the noise level is decreasing: at a distance of 15 metres from the lot the noise is only $40-45 \mathrm{dBA}$. The noise level obtained in the area of the lot during numeral simulation corresponds to the noise level obtained during measuring. During measuring the noise level recorded at the spots located closer to the street was 49-50 dBA, on other spots it was $47-45 \mathrm{dBA}$. The equivalent noise level regulated by hygiene norms is exceeded only close to the street. Fig 7 clearly illustrates the zones of the noise shadow 


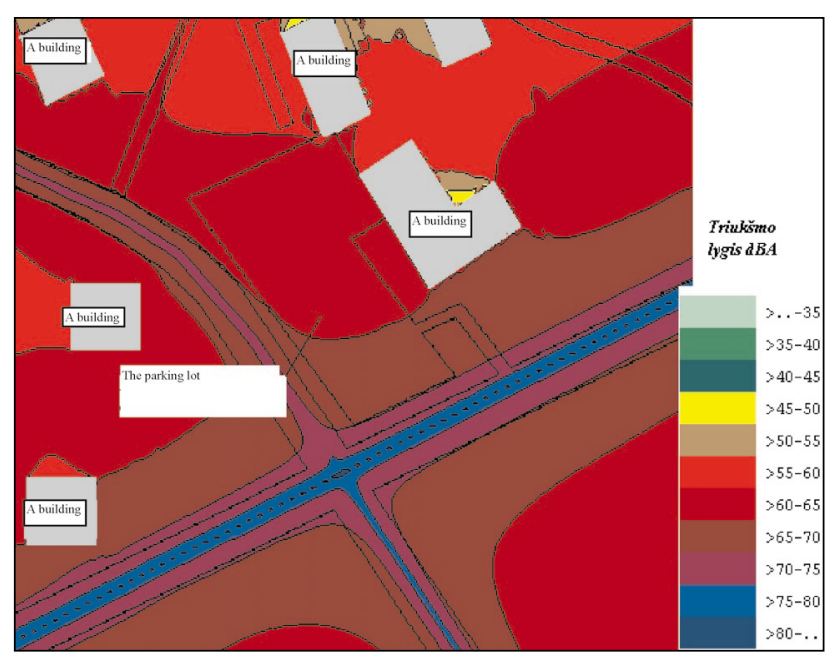

Fig 8. Results of the simulation of noise dispersion at the parking lot on Ateities street

occurring due to buildings. Behind the houses, built on the western side of the area being tested which are at a distance of 100 metres from the lot, the noise level is only $35 \mathrm{dBA}$. This is because buildings screen the noise. Behind the buildings, dimensions of which are not sufficient for noise screening, the noise level is only 40 $35 \mathrm{dBA}$. The grove situated behind the area of the lot also has an impact on the noise decrease.

The results of the numeral simulation of the noise level at the parking lot on Ateities street are illustrated in Fig 8.

From the data of Fig 8 it is evident that the noise level is higher than the equivalent noise level permitted by the Hygiene Norm which in a residential environment should not exceed $55 \mathrm{dBA}$. Almost the whole tested area is covered with colours denoting the noise level of not less than $55 \mathrm{dBA}$. The highest noise level has been recorded in the part of the lot located close to the crossing of two heavy traffic streets. There the noise level is 65-70 dBA. In the remaining part of the lot the noise level is $60-65 \mathrm{dBA}$. Receding from the area of the lot, the noise level goes down: on the western side of the area tested - approximately 100 metres away form the boundary of the lot - it is $60-65 \mathrm{dBA}$, on the northern side of the area tested - approximately 20 metres away from the area of the lot - it is $55-60 \mathrm{dBA}$, and in the southern part of the lot the limit of $60-65 \mathrm{dBA}$ is reached only at a distance of 200 metres due to the crossing of two heavy traffic streets. Such results of numeral simulation correspond to the data of testing. In the part of the parking lot close to the crossing the measured noise level is $67-71 \mathrm{dBA}$. The permitted noise level is exceeded there due to the crossing of two heavy traffic streets. In areas close to residential dwellings the noise level exceeds that permitted by hygiene norms by 10 15 dBA. An acoustic comfort is reached only in the zones of an acoustic shadow which gets formed behind

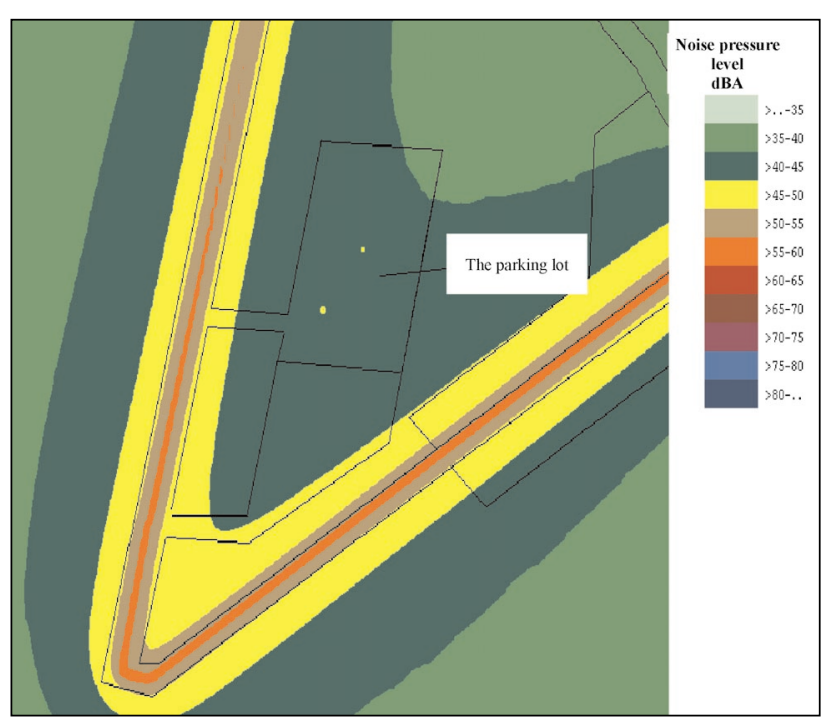

Fig 9. Results of the simulation of noise dispersion at the parking lot on Č. Sugihara street

buildings. The noise map shows that in these zones the noise level is $45-55 \mathrm{dBA}$. The noise level goes down receding from the noisy crossing. To obtain on acoustic comfort, it is necessary to take specific measures for noise level reduction. The noise generated at the parking lot has a rather insignificant impact on the total noise level of this area.

The results of the numeral simulation of the noise level carried out at the parking lot on C. Sugihara street are presented in Fig 9.

Fig 9 shows that traffic on $\breve{C}$. Sugihara street passing close to the lot is not heavy (on the average 5-10 motor vehicles per hour); however, the highest noise level is recorded exactly in the area close to the street but not at the parking lot. In this part of the area the noise level is $45-55 \mathrm{dBA}$. In the whole area of the parking lot the noise level is $40-45 \mathrm{dBA}$. Several yellow patches seen in the area of the parking lot denote the noise level of 45-50 dBA. At these spots the noise level was the highest during testing. Receding from the area of the lot the noise level goes down to 35-40 dBA. Such a noise level is achieved at a distance of 50 metres in all directions. The noise level at the parking lot does not exceed the noise level permitted by the Hygiene Norm. This is due to the fact that the parking lot is situated in a remote place, away from busy streets. Only 10-15 motor vehicles per hour pass Č. Sugihara street. The noise generated by the vehicles parked on the lot has a little impact on the background noise level of surrounding areas.

\section{Conclusions}

1. The noise generated by the motor vehicles parked on parking lots does not have any significant impact on the background noise prevailing in the area. As the parking lot on Č. Sugihara street is away from busy streets, 
the noise level recorded at this lot is the best reflection of the noise level generated only by the vehicles kept on the lot, and this level does not exceed the level permitted by the Hygiene Norm.

2. The noise level at the parking lots tested is conditioned by the noise level coming from nearby streets. A higher noise level is recorded at the measuring spots that are at the closest distance from streets.

3. The highest noise level prevails in the area of the lot from 6 a.m. to 8 a.m. and from 5 p.m. to 8 p.m., as at that time the traffic of motor vehicles is the heaviest on the lot. At this time of the day the noise level recorded at the lot on C. Sugihara street is on the average equal to $47 \mathrm{dBA}$, and during the rest of the day it is lower by $15-20 \mathrm{dBA}$.

4. At parking lots located close to busy streets the prevailing noise level exceeds the permitted noise level. At the parking lot on Ateities street the noise level recorded exceeds the noise level permitted by the Hygiene Norm HN 33:2001 by 5-10 dBA.

5 . The simulation of noise dispersion carried out with the help of the software IMMI has proved the results obtained during measuring. The noise levels marked on the noise map of the parking lots tested correspond to the noise levels recorded during measuring. The noise level measured at the lots differs from the noise level obtained during numeral simulation by $1-2 \%$. The noise level in the areas at a distance of some 30-50 metres from the boundaries of the parking lot decreases by 10 15 dBA.

\section{References}

1. Smoot, J. L.; Cox, C.D.; and Turpin, A. M. Laboratory Testing of a System to Treat Highway Stormwater in Karst Areas. The Engineering Geology and Hydrogeology of Karst Terranes. Balkema, Rotterdam: Beck \& Stephenson, 1997. 49 p.

2. Eibeheiry E. M. Effects of small travel speed variation on active vibration control in modern vehicles. Journal of Sound and Vibration, Vol 232 (5), 2000, p 857-875.

3. http://www.vmvsc.lt Traffic noise in Vilnius city. $2000 \mathrm{~m}$. (in Lithuanian).

4. Klibavičius, A. Assessment of transport negative impact (Transporto neigiamo poveikio aplinkai vertinimas). Vilnius: Technika, 1998. 40 p (in Lithuanian).

5. Juodzevičius, E. Evaluation of motor transport technical state by their engine noise. Transport Engineering (Transportas), Vol XVI, No 6. Vilnius: Technika, 2001, p 234-239 (in Lithuanian).

6. Sanford, F. Updating a dosage-effect relationship for prevalence of annoyance to general transportation noise. J. Acoust. Soc. Am, 89(1). 1999, p 221-233.

7. Merkevičius, S.; Deikus, J. Acoustic pollution of light duty wheeled tractors. Environmental Engineering (Aplinkos inžinerija), Vol VI, No 1. Vilnius: Technika, 1998, p 3743 (in Lithuanian).

8. Žeromskas, R. Basic characteristics of environmental protection in load transport of Lithuania. Environmental Engineering (Aplinkos inžinerija), Vol VI, No 4. Vilnius: Technika, 1998, p 140-145 (in Lithuanian).
9. http://www.defra.gov.uk Noise mapping. 2000

10. ISO 9613-2. Acoustics - Attenuation of sound during propagation outdoors - General method of calculation.

11. Scherbavich, E. V. The problems of acoustic noise (Проблемы акустического шума). Moscow: Transport, 1999. 125 p (in Russian).

\section{TRIUKŠMO AUTOMOBILIŲ STOVĖJIMO AIKŠTELĖSE TYRIMAI IR JO SKLIDIMO SKAITINIS MODELIAVIMAS}

\section{P. Baltrẻnas, D. Kazlauskas, E. Petraitis}

\section{Santrauka}

Vilniuje ir kituose didesniuose miestuose mobiliujų šaltinių skleidžiamas triukšmas sudaro iki $90 \%$ viso miesto triukšmo lygio. Aukštas triukšmo lygis esti automobilių stovejimo aikštelèse. Siekiant ji ivvertinti atlikti tyrimai. Saugomas automobilių stovejimo aikšteles suskirsčius pagal pobūdi, pasirinkta po vieną skirtingo tipo aikštelę. Matavimo taškų skaičių lèmė aikštelès dydis. Gauti tyrimų duomenys rodo, kad didžiausias triukšmas sklinda ne iš pačios automobilių stovejjimo aikštelès, o iš šalia esančios gatvès. Tokią išvadą irodo triukšmo lygio automobilių stovejimo aikštelèje Č. Sugiharos gatvejje tyrimo rezultatai. Nors šioje aikštelejje saugoma per 100 automobiliu, tačiau nustatyta, kad joje ekvivalentusis triukšmo lygis - 47 dBA. Remiantis tyrimų duomenimis, atliktas triukšmo sklidimo i šalia automobilių stovejjimo aikšteliu esančią teritoriją skaitinis modeliavimas. Modeliavimui naudojama skaitinio modeliavimo programa IMMI.

Raktažodžiai: transportas, triukšmas, automobilių aikštelès, modeliavimas, skaitinis.

\section{ИССЛЕДОВАНИЕ УРОВНЯ ШУМА НА АВТОСТОЯНКАХ И МОДЕЛИРОВАНИЕ ЕГО РАСПРОСТРАНЕНИЯ}

\section{П. Балтренас, Д. Казлаускас, Э. Петрайтис}

Резюме

В Вильнюсе и других больших городах Литвы уровень шума, распространяемого от мобильных источников, составляет почти $90 \%$ общего уровня шума окружающей среды. Велик уровень шума на автостоянках. С целью установить величину этого уровня на охраняемых автостоянках были проведены исследования. Все автостоянки были подразделены на группы. Шум измерялся на одной автостоянке каждой группы, обращалось внимание на окружающую среду автостоянки. Количество точек измерения находилось в зависимости от величины автостоянки. Наибольший уровень шума зарегистрирован не на автостоянке, а на расположенной рядом с ней улице. Характерным примером может служить автостоянка, которая находится около улицы Ч. Сугихары. Хотя на автостоянке устроено свыше ста мест для автомобилей, однако рядом с ней нет больших улиц, и поэтому измеренный на ней уровень шума не достигает 47 дБ(А). Для моделирования изменения уровня шума на территориях, находящихся около автостоянок в городе Вильнюсе, была использована программа IMMI.

Ключевые слова: уровень шума, автостоянки, численное моделирование. 